\title{
Bolsovian Calamostachys incrassata (Němejc) emend. and its spores from the Kladno-Rakovník Basin of the Czech Republic
}

\author{
MILAN LIBERTÍN \& JIŘí BEK
}

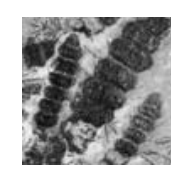

\begin{abstract}
The present article recommends the emendation of the species Calamostachys incrassata, proposed by Němejc (1953), which was based on one specimen from the Rako Mine near Lubná in the Kladno-Rakovník Basin. The stratigraphical position of the specimen is the Lower Bolsovian. The inner morphology of Calamostachys incrassata and its in situ spores are described for the first time. The morphology of Calamostachys incrassata cones differs from that of all other known species of calamitean strobili. Most in situ microspores possess a very thin pseudosaccus-like layer that envelopes the trilete inner body of the Calamospora-type. Microspores with an outer exine layer are morphologically similar to some dispersed miospore species of the genera Auroraspora, Remysporites, Callialasporites, Perotrilites, Phyllothecotriletes and Diaphanospora. $\bullet$ Key words: Calamites, in situ spores, Calamospora, Calamostachys, Pennsylvanian, Czech Republic.
\end{abstract}

LiBerTín, M. \& BeK, J. 2006. Bolsovian Calamostachys incrassata (Němejc) emend. and its spores from the Kladno-Rakovník Basin of the Czech Republic. Bulletin of Geosciences 81(3), 207-213 (4 figures). Czech Geological Survey, Prague. ISSN 1214-1119. Typescript received April 4, 2006; accepted in revised form September 2, 2006; issued September 30, 2006.

Milan Libertín, National Museum, Václavské náměstí 64, 11821 Prague 1, Czech Republic; milan_libertin@nm.cz• Jiř Bek, Academy of Sciences of the Czech Republic, Institute of Geology, Laboratory of Palaeobiology and Palaeoecology, Rozvojová 269, 16500 Prague 6, Czech Republic; mrbean@gli.cas.cz.

Calamitean plants and their fragments, such as leaves, trunks, branches, roots and cones, are relatively common Carboniferous plant fossils. Calamitean plants included arborescent (some with secondary xylem) and herbaceous forms. Compressed fossil trunks and their fragments are usually assigned to the genera Calamites Suckow, Mesocalamites Hirmer, Neocalamites Halle, Stylocalamites Weiss, Calamitina Weiss or Eucalamites Weiss. Calamitean roots are usually referred to the genera Myriophyllites Artis, Pinnularia Lindley \& Hutton, Astromyelon Williamson, or Myriophylloides Hickley \& Cash. Calamitean leaves are commonly described as belonging to the genera Annularia Sternberg, Calamariophyllum Hirmer, or Asterophyllites Brongniart. Cones of calamitean plants belong to several organ-genera, the most common of which are Calamostachys Schimper, Palaeostachya Weiss, Macrostachya (Germar) Zeiller, Huttonia Sternberg, Paracalamostachys Weiss, Mazostachys Kosanke, Cingularia Weiss, Pothocites Kidston, and Weissistachys Rothwell $\&$ Taylor.

The sporangia of calamites are grouped in whorled strobili, which can either possess or lack sterile bracts. Some species of these genera are known only as compres- sions, while others are preserved as petrifactions in coalballs, i.e. they may represent different preservational variants. Our opinion (Bek 1998) is that most of calamitean cone taxa were bisporangiate, though several of them have been described as monosporangiate (Balme 1995). The micro- and megaspores of these equisetalean plants are among the simplest spore types (simple trilete laesurae, thin and laevigate exine), and can be assigned to the dispersed spore genus Calamospora Schopf, Wilson \& Bentall. Micro- and megaspores differ only in diameter, as calamitean megaspores are usually only a few times larger than their microspores, in contrast to much larger examples like lycopsid megaspores.

The first important palynological research of calamitean in situ micro- and megaspores was published by Hartung (1933), who isolated them from fifteen species referred to the genera Calamostachys, Macrostachya, Huttonia, Palaeostachya and Paracalamostachys.

Later authors did not systematically study calamitean fructifications, but only published particular results usually based on the study of one or a few specimens (e.g., Kosanke 1955, Arnold 1958, Remy 1959, Baxter 1963, Serret \& Brousmiche 1987, Lugardon \& Brousmiche-Delcambre 


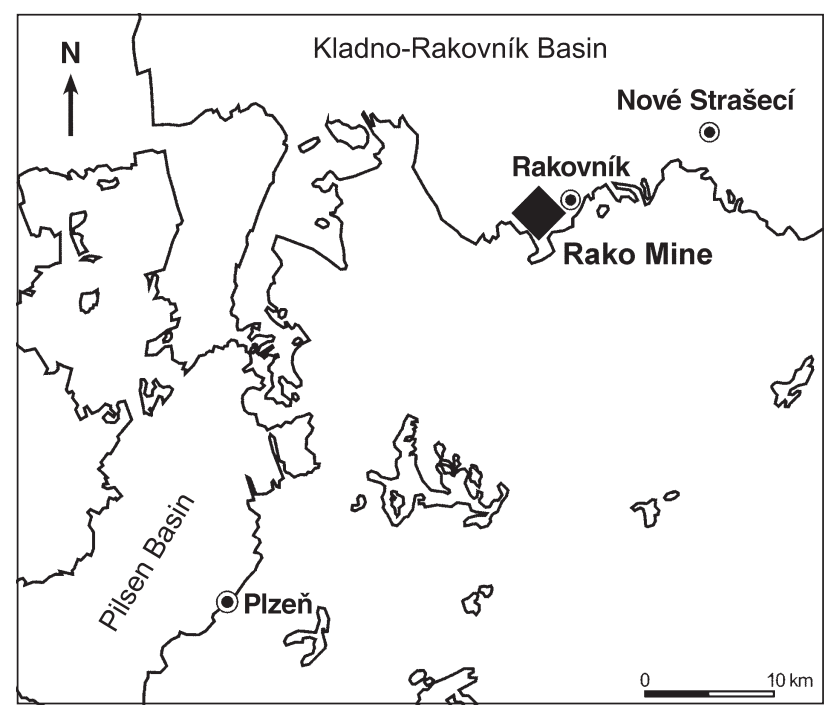

Figure 1. Map showing the geographical position of the locality of Calamostachys incrasata (Němejc) emend.

1994). Boureau (1964) gave an overview of calamitean plants and their reproductive organs, sometimes including in situ spores, and Balme (1995) concentrated on a review of calamitean in situ spores. Good $(1975,1977)$ and Good \& Taylor (1974) described in situ calamospores from petrified American specimens of Calamostachys binneyana (Carruthers) Schimper, C. inversibractis Good, Pendulostachys cingulariformis Good, Palaeostachya andrewsii Baxter and P. decacnema Delevoryas. Some of these possess delicate elaters, and Good $(1975,1977)$ supposed that most calamospores were enveloped by three-coiled elaters in their earlier ontogentic stages, and that the elaters may have unrolled during the ontogeny and are not usually preserved due to their delicate character. It is significant that almost all in situ and dispersed calamospores with elaters are reported from petrified specimens. Some authors (Bek 1998, 2000; Libertín \& Bek 2004) have studied and observed hundreds slides with Bohemian Pennsylvanian in situ calamospores isolated from compression specimens of seventeen species of the genera Calamostachys, Palaeostachya, Macrostachya and Huttonia, and never observed any elaters.

The first descriptions of Carboniferous calamitean plants from continental basins of the Czech Republic were published by Sternberg (1820-1838), Presl (1838) and Feistmantel (1871). Němejc (1953) described nineteen species (including six new) of the genera Palaeostachya, Calamostachys, Huttonia and Macrostachya from the coal districts of central Bohemia. Němejc based his results only on the cone morphology and did not mention any spores. Bek (1998) and Bek \& Opluštil (1998) described in situ spores from Bohemian calamitean fructifications for the first time.
Němejc (1953) proposed the new species Calamostachys incrassata from the Lower Bolsovian of the KladnoRakovník Basin. Later, Bek (1998) isolated in situ microspores named as Calamospora cf. microrugosa (Ibrahim) Schopf, Wilson \& Bentall from the type specimen of $C$. incrassata, and mentioned the occurrence of microspores with pseudosaccus-like layers. We have studied the inner morphology of this specimen and its in situ spores to determine its precise affinity and classification.

\section{Material and methods}

Fig. 1 shows the geographical position of the locality of Calamostachys incrassata. Specimen E1141 with strobili, and the slides with in situ microspores are housed in the National Museum, Prague, Czech Republic. A small sample of radially arranged sporangia (Fig. 3G) from a node was taken for the precise description of the cone. This sample was macerated in Schultze's solution with $\mathrm{KOH}(5 \%)$. The sample was mechanically divided lengthwise along the axis of the cone (Fig. 3B, D-F). Digital photomicrographs of all in situ microspores are stored in the Laboratory of Palaeobiology and Palaeoecology, Institute of Geology, Czech Academy of Sciences, Prague. Spores were recovered by dissolving small portions of sporangia in nitric acid for 24-40 hours and in $\mathrm{KOH}$ for 1 hour. All spores were mounted in glycerine jelly for direct microscopic examination. Photomicrographs were made using a Olympus C330s digital camera on an Olympus BX51 microscope. The terms used for the descriptions of in situ spores were obtained from the latest edition of the Glossary of pollen and spore terminology (Punt et al. 1994). In situ spores are compared according to the system of classification of dispersed spores suggested by Potonié \& Kremp (1954, 1955), Dettmann (1963) and Smith $\&$ Butterworth (1967).

\section{Systematic part}

Order Calamitales

Family Calamitaceae

Genus Calamostachys Schimper, 1869

Type species. - Brukmannia tuberculata Sternberg, 1825

Calamostachys incrassata (Němejc) emend. Figures 2-4, 3A-G, 4A-L

1953 Calamostachys incrassata n. sp.; Němejc, pp. 31-33, pl. 4., figs 4-6. 


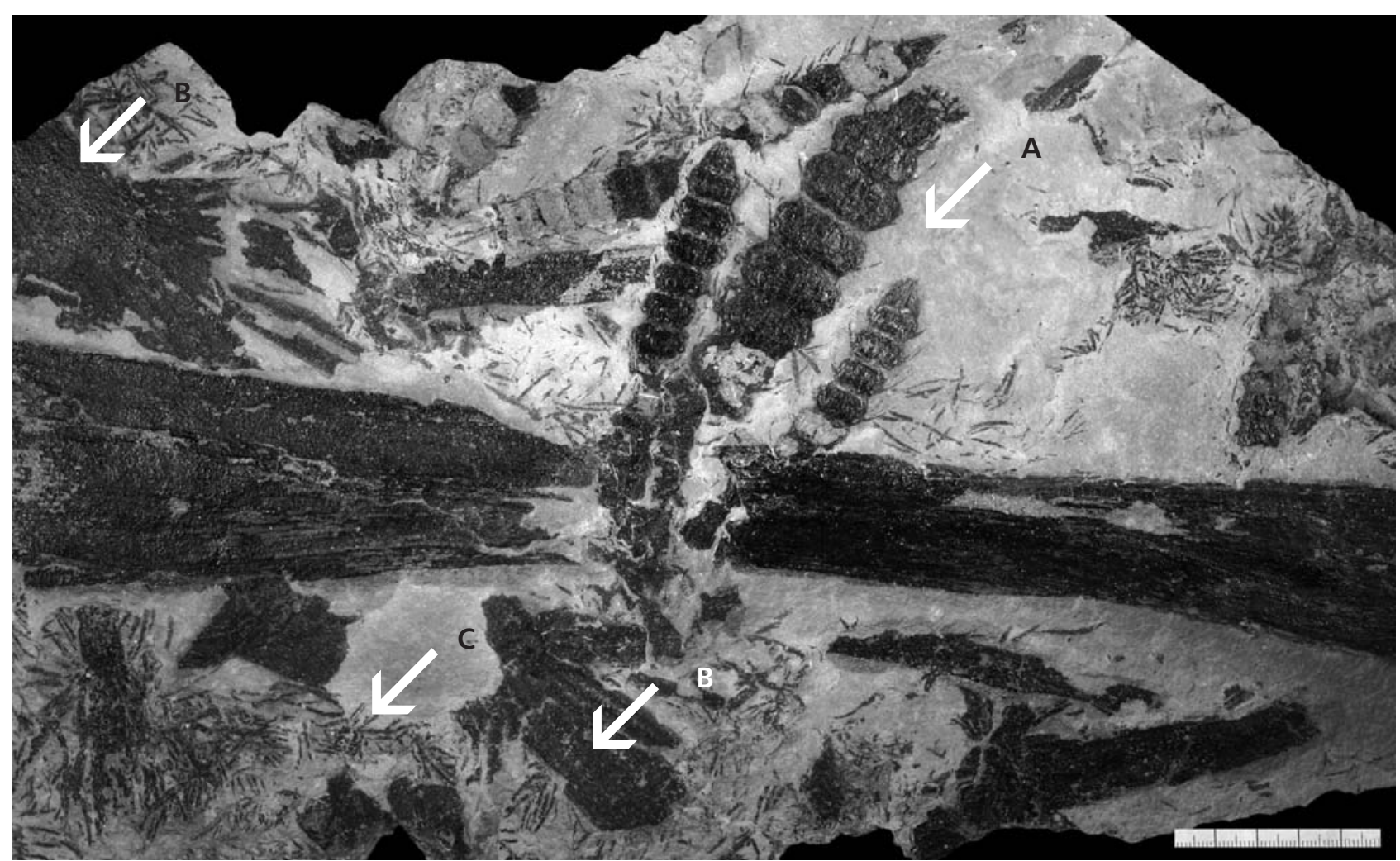

Figure 2. Calamostachys incrassata (Němejc) emend., E1141. • A - grape-like group of cones. • B - collar-like connate leaves resemble the genus Calamariophyllum Hirmer. $・ \mathrm{C}$ - fragments of thin leafy branches resemble the genus Asterophyllites sp.

1998 Calamostachys incrassata Němejc; Bek, pp. 128, 129, pls $115,116$.

Holotype. - Specimen E1141, National Museum, Prague.

Type locality. - Rako Mine, near Lubná, Kladno-Rakovník Basin, central Bohemia, Czech Republic.

Type horizon. - Radnice Member, Lower Bolsovian, Pennsylvanian.

Emended diagnosis. - Calamitean cones 10-26 mm thick and 70-130 $\mathrm{mm}$ long. The single fertile internodes resp. whorls with their bracts upwards, bent arc-like around the sporangiophores, are generally barrel-like, inflated and mostly shorter than broad. Sporangiophores are distally detached within the lower third of internodes with an angle of $85^{\circ}$. Each sporangiophore bears 2 circular sporangia, which are sub-terminally located. Their sterile bracts are linear, lanceolate, slowly attenuating to a sharp point; their end portions are mostly slightly declinated from the cone body. Their tops reach up to one-quarter of the next higher neighbouring fertile internode.

Circular to oval trilete microspores. Laevigate thin exine. Sometimes pseudosaccus-like layer envelopes inner body.
Description. - Strobili possess cylindrical shape with prominent nodes (Fig. 2A-C). The strobili are $80-120 \mathrm{~mm}$ long and 13-26 mm wide. Internodes are $8 \mathrm{~mm}$ long, axis of the cone is $3 \mathrm{~mm}$ wide. Sterile bracts are lanceolate, 12-16 mm long, and almost twice longer than internoades. Sporangiophores are distally detached in the lower third of internodes with an angle of $85^{\circ}$ (Fig. 3D, F). Each sporangiophore bears two spherically flattened sporangia (Fig. 3A, B) which are sub-terminally arranged on sporangiophore.

Twenty-eight sporangiophores are radially arranged. Sporangium on adaxial surface is always smaller. The diameter of spherical sporangia is $3-4 \mathrm{~mm}$, their surface is smooth and cuticular cells are arranged in vertical rows (Fig. 3A, C). Two types of sterile equisetalean leaves occur together with reproductive organs. Collar-like connate leaves of the Calamariophyllum-type occur on nodes of thicker branches. Sometimes crooked fragments up to $50 \mathrm{~mm}$ in diameter of the Asterophyllites-type occur.

Němejc (1953) never observed any specimens in which such cones were attached terminally or at the nodes of several leaves bearing thinner side branches.

Most specimens described herein show only impressions of their outer surface. Only one specimen, which exhibits another kind of preservation (having all spaces between the bracts, sporangiophores and the cone axis filled 

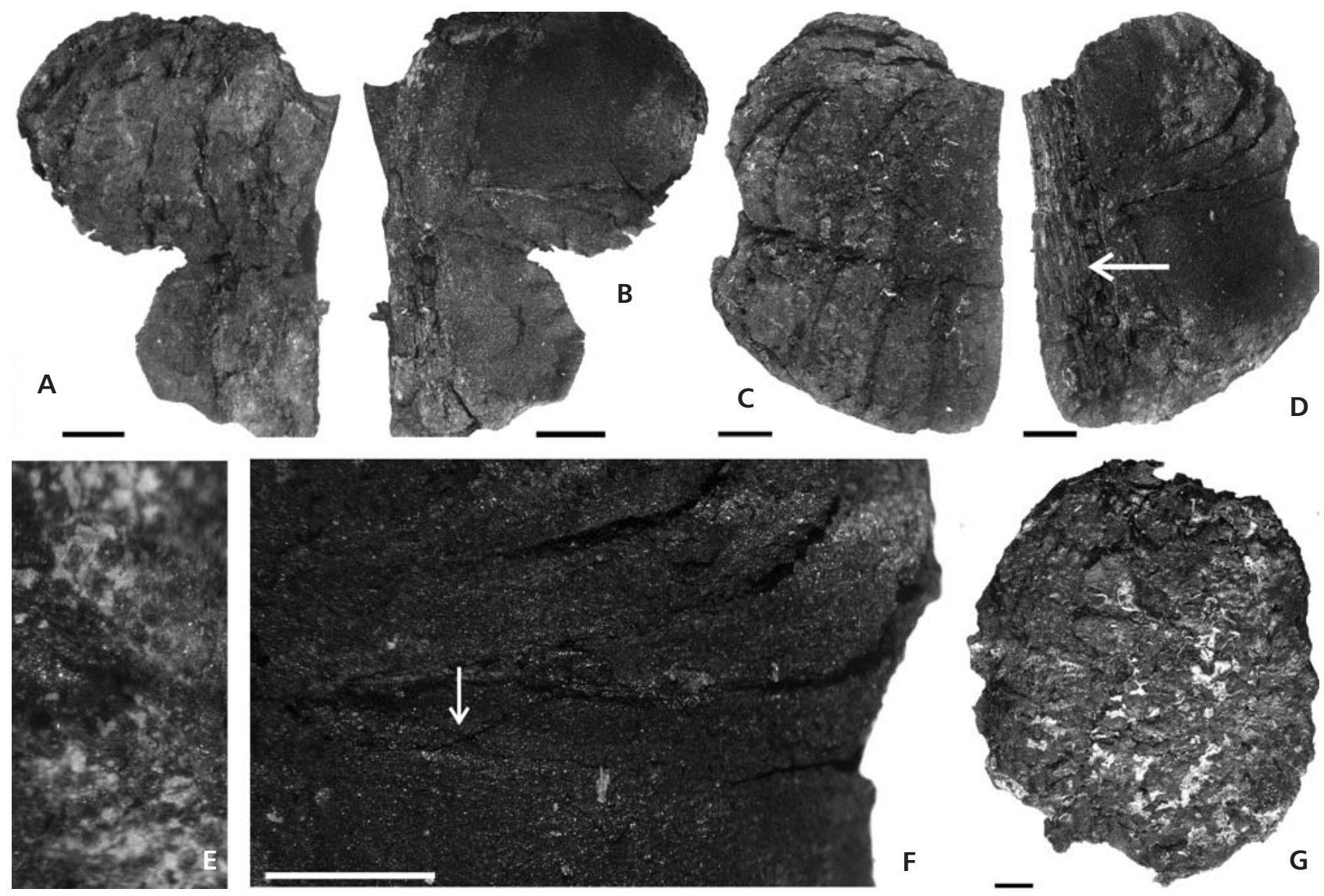

Figure 3. Calamostachys incrassata (Němejc) emend., E1141. • A - external view on radially arranged sporangia. • B - longitudinal section of sporangia on sporangiophore. $\bullet \mathrm{C}$ - external view on radially arranged sporangia. $\bullet \mathrm{D}-$ cross section of sporangia on sporangiophore. Arrow marks the axis of the cone. $\bullet \mathrm{E}$ - detail of spores inside the sporangium. $\bullet \mathrm{F}$ - detail of sporangiophore (marked by the arrow). $\bullet \mathrm{G}-$ radially arranged sporangia before the maceration. Scale bar is $1 \mathrm{~mm}$.

in by a fine kaolinic substance) and which is partly crushed along its cone axis, clearly showed the position of the sporangiophores. This fragment is $70 \mathrm{~mm}$ long, 14-15 mm wide, and its axis is $3-4 \mathrm{~mm}$ thick. The attachments of the sporangiophores are situated between the neighbouring sterile whorls, i.e. in the same way as in C. tuberculata.

Circular, subcircular to oval trilete microspores 45 (73.22) $91 \mu \mathrm{m}$ in diameter. Rays of trilete mark one-third to one-half of radius. Sometimes labrum 2-4 $\mu \mathrm{m}$ high and wide. Exine of inner body is $1-2 \mu$ m thick. Several compression folds of exine occur. Most microspores possess very thin and delicate pseudosaccus-like layer enveloping the inner body. No germination-like apparatus is observed on the pseudosaccus-like layer.

Remarks. - Most of microspores are enveloped in a pseudosaccus-like layer, which can be damaged and preserved only in fragments.

Comparison. - The morphology of Calamostachys incrassata cones differs from that of all other known species of calamitean strobili. The general morphology corresponds with the generic diagnosis of Calamostachys. Němejc (1953) compared this species with the genus Calamostachys, probably due to the unknown position of the sporangiophores. Calamostachys incrassata differs from $C$. tuberculata in the size and shape of the sterile bracts and in the number of sporangia (C. tuberculata possesses 4 sporangia per sporangiophor). The sporangia of Calamostachys incrassata are double the size of those of $C$. tuberculata. Sternberg's type material of $C$. tuberculata was used for this comparison. C. northumberiana Kidston differs in the general size and shape of sterile bracts, which are broadly lanceolate in shape with rounded tip, and are not longer than the internodes. C. solmsii Weiss has a different size and its sporangia are known only as imprints. Simpson-Scharold (1934) mentioned cones of comparable size from a similar stratigraphic position in the Saar Basin, Germany, but the position of sporangia is not described and therefore it is impossible to compare them with Bohemian specimen of Calamostachys incrassata.

Distribution. - Calamostachys incrassata is known hitherto only from the tuffitic sandstone bed of the Upper 
Milan Libertín \& Jiří Bek • Bolsovian Calamostachys incrassata and its spores from the Kladno-Rakovník Basin
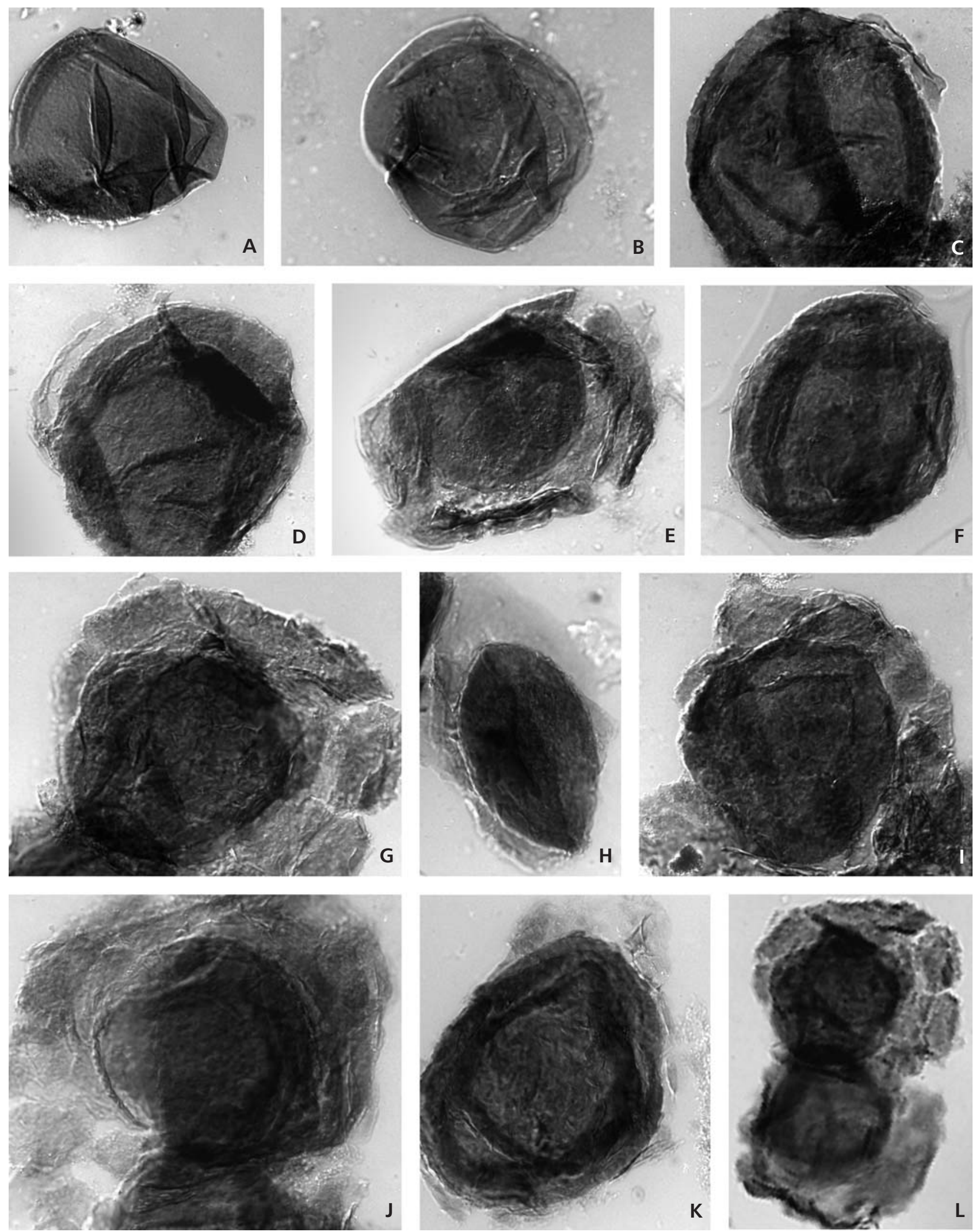

Figure 4. A, B - in situ spores of the calamospora-type isolated from Calamostachys incrassata (Němejc) emend., E1141. Two specimens without outer exine layer. $\times 500$. $\bullet \mathrm{C}-\mathrm{L}-$ in situ spores of the Calamospora-type isolated from Calamostachys incrassata (Němejc) emend., E1141. Specimens with more or less preserved outer exine layer. All $\times 500$ 
Lubná coal seam of the Lubná coal measure series in the Lower grey beds of the Rako Mine at "Krčelák", near Rakovník.

\section{Discussion on microspores}

Microspores of the Calamospora-type enveloped in a delicate pseudosaccus-like layer have been reported by Barthel (1976), Serret \& Brousmiche (1987), Coquel \& Brousmiche-Delcambre (1996), Bek \& Opluštil (1998), Bek (1998) and Libertín \& Bek (2004) from strobili of the genera Palaeostachya, Calamostachys and Huttonia. These spores have sometimes been interpreted as pseudosaccate (Coquel \& Brousmiche-Delcambre 1996) and were assigned to the dispersed genera Auroraspora Hoffmeister, Staplin \& Malloy, Perotrilites (Erdtman) Couper, Remysporites, Callialasporites, Phyllothecotriletes Luber or even Diaphanospora (Balme \& Hassell) Evans. Bek (1998) described similar forms from specimens of Palaeostachya ettingshausenii Kidston, P. distachya Sternberg, Calamostachys cf. ramosa Weiss and C. longibracteata Němejc from the Pennsylvanian of the Czech Republic. Barthel (1976) reported similar microspores from Calamostachya calathifera (Weiss) Jongmans from Germany. Serret \& Brousmiche (1987) described the same pseudosaccus-like layer on the microspores of Calamostachys williamsoniana Weiss, and Coquel \& Brousmiche-Delcambre (1996) reported it from Palaeostachya feistmantelii Němejc, Calamostachys calathifera, C. binneyana (Carruthers) Schimper and C. germanica Weiss.

Microspores that lack the pseudosaccus-like layer are comparable with several dispersed species of Calamospora. The determination of dispersed calamospores is based on the differences in the diameter, shape, and length of laesurae, the occurrence of a dark contact area, and the number, shape, size and position of the exine compression folds. In fact, none of these features are primary factors for characterising calamospore species, but depend on the mode of preservation and fossilisation, and are therefore highly variable. For example, the diameter of in situ calamospores isolated from a strobilus can depend on the position of their sporangia. Microspores from basal parts of the cones are often larger than those from apical sporangia (Bek 1998). But some microspores isolated from a single sporangium can also differ in diameter, e.g. in situ calamospores of Palaeostachya elongata (Presl) Weiss are from 35 to $152 \mu \mathrm{m}$ in diameter (Bek 1998). Furthermore, their shapes differ from circular to subcircular, subtriangular and oval.

The number, position, shape and size of the exine compression folds also vary widely. Some dispersed species of Calamospora are characterised by the type of compression folds, e.g., Calamospora pedata Kosanke, C. breviradiata Kosanke, C. parva Guennel or C. straminea Wilson \& Kosanke. For example, oval microspores with a large compression fold covering half of the body and assigned to the dispersed species $C$. pedata Kosanke, can be recognised in every slide with in situ calamospores. Other features, such as the length of laesurae and the occurrence of the dark proximal contact area, can also vary within in situ calamospores isolated from one calamitean cone, as mentioned by Good (1977) and Bek (1998). On the other hand, microspores of one morphological type (i.e. with or without contact area, or with or without a labrum) prevail in about $75 \%$ of all specimens (Bek 1998).

\section{Conclusions}

The diagnosis of the species Calamostachys incrassata is emended based on new information, especially regarding the position of sporangia and the description of in situ spores. Cones are characterised by their verticels of sporangiophores, which are attached at an angle of $85^{\circ} \mathrm{mid}-$ way between successive verticels of sterile bracts. The latter confirms that the specimens belong to the genus $\mathrm{Ca}$ lamostachys. C. incrassata is characteristic of the Lubná Coal Group, and it is possible that this or similar species occur within the same stratigraphical position in the Saar Basin, Germany. In situ spores isolated from Calamostachys incrassata were described here for the first time.

Most microspores of Calamostachys incrassata are enveloped in a thin delicate pseudosaccus-like layer, and may resemble some specimens of the dispersed spore genera Auroraspora, Remysporites, Callialasporites, Perotrilites, Phyllothecotriletes and Diaphanospora. Only a minority of them lack this layer and can be correlated with several dispersed species of the genus Calamospora. A similar thin pseudosaccus-like layer is reported from other species of the genera Palaeostachya, Calamostachys and Huttonia. We suppose that the occurrence of a delicate pseudosaccus-like layer is not of ontogenetic origin, but that it is a significant morphological feature of spores of Calamostachys incrassata. This feature distinguishes $C$. incrassata from most of other calamitean cones.

\section{Acknowledgements}

We acknowledge financial support from the Grant Agency of the Academy of Science of the Czech Republic (project A 3013902), (CEZ: Z3013912) of the Institute of Geology, Academy of Sciences, Prague. Many thanks to Jiřina Dašková from the Laboratory of Palaeobiology and Palaeoecology, Institute of Geology, Academy of Science of the Czech Republic, Prague. 


\section{References}

ARnOLD, C.A. 1958. Petrified cones of the genus Calamostachys from the Carboniferous of Illinois. Contributions from the $\mathrm{Mu}$ seum of Palaeontology 14, 149-165.

BALME, B.A. 1995. Fossil in situ spores and pollen grains: An annotated catalogue. Review of Palaeobotany and Palynology 87(2-4), 81-323.

BARTHEL, M. 1976. Die Rotliegendflora Sachsens. Abhandlungen des Staatlichen Museums für Mineralogie und Geologie zu Dresden 24, 1-190.

BAXTER, R.V. 1963. Calamocarpon insignis, a new genus of heterosporous petrified calamitean cones from the American Carboniferous. American Journal of Botany 50, 469-476.

BEK, J. 1998. Spore populations of some plants of groups Lycophyta, Sphenophyta, Pteridophyta and Progymnospermophyta from Carboniferous limnic basins of the Czech Republic. $\mathrm{PhD}$ thesis, Geological Institute of the Academy of Sciences of the Czech Republic, Prague.

BEK, J. 2000. Carboniferous Calamospora: How many ways of origin?, 10. In WANG, W., OUYANG, S., Sun, X. \& Zu, G. (eds) Abstracts, $10^{\text {th }}$ International Palynological Congres, June 24-30, Nanjing.

BeK, J. \& OpluštiL, S. 1998. Some lycopsid, sphenopsid and pteropsid fructifications and their miospores from the Upper Carboniferous basins of the Bohemian Massif. Palaeontographica B 248, 127-161.

Boureau, E. 1964. Traité de Paléobotanique III. Sphenophyta: Noeggerathiophyta. 544 pp. Masson, Paris.

Coquel, R. \& Brousmiche-Delcambre, C. 1996. Comparaisons spores in situ-spores dispersées chez quelques Equisétales, Marattiales et Lépidodendrales du Carbonifere supérieur: Considérations sur l'utilisation de morphoespeces en paléopalynologie. Revue de Paléobiologie 15(1), 121-154.

DetTMAnN, M.E. 1963. Upper Mesozoic microfloras from south-eastern Australia. Proceedings of the Royal Society of Victoria 77, 1-148.

Feistmantel, O. 1871. Steinkohlenflora von Kralup in Böhmen. Abhandlungen der Königlichen Böhmischen Gesellschaft der Wissenschaften 6(5), 1-38.

GooD, C.W. 1975. Pennsylvanian-age calamitean cones, elater-bearing spores and associated vegetative organs. Palaeontographica B 153, 28-99.

GooD, C.W. 1977. Taxonomic and stratigraphic significance of the dispersed spore genus Calamospora, 43-64. In Romans, R.C. (ed.) Geobotany. Plenum, New York.

GoOD, C.W. \& TAYLOR, T.N. 1974. The establishment of Elaterites triferens spores in Calamocarpon insignis microspo- rangia. Transactions of the American Microscopical Society 93(1), 148-151.

HaRtung, W. 1933. Die Sporenverhaltnisse der Calamariaceen. Arbeiten aus dem Institut für Paläobotanik und Petrographie der Brennsteine 3(1), 96-149.

KosANKE, R.M. 1955. Mazostachys, a new calamite fructification. Illinois State Geological Survey, Report of Investigations 180, 7-24.

Libertín, M. \& BeK, J. 2004. Huttonia spicata (Sternberg) emend. and its spores, the Radnice Basin (Bolsovian), Carboniferous continental basins of the Czech Republic. Review of Palaeobotany and Palynology 128, 247-261.

Lugardon, B. \& Brousmiche-Delcambre, C. 1994. Exospore ultrastructure in Carboniferous sphenopsids, 53-66. In KuRMANN, M.H. \& DoYLE, J.A. (eds) Ultrastructure of fossil spores and pollen. Royal Botanic Garden, Kew.

NĚMEJC, F. 1953. Taxonomical studies on the fructifications of the Calamitaceae collected in the coal districts of Central Bohemia. Sborník Národního muzea v Praze, B, 9(1), 3-62.

Potonié, R. \& KREMP, G. 1954. Die Gattungen der paläozoischen Sporae dispersae und ihre Stratigraphie. Geologisches Jahrbuch 69, 111-193.

PotoniÉ, R. \& KREMP, G. 1955. Die Sporae dispersae des Ruhrkarbons ihre Morphographie und Stratigraphie mit Ausblicken auf Arten anderer Gebiete und Zeitabschnitte. Teil I. Palaeontographica B 98(1/3), 1-136.

PRESL, K.B. 1838. Beiträge zur Kunde vorweltlicher Pflantzen. Verhandlungen der Gesellschaft des Vaterländischen Museums in Böhmen, 1-26.

Punt, W., Blackmore, S., Nilsson, S. \& Le Thomas, A. 1994. Glossary of pollen and spore terminology. $71 \mathrm{pp}$. LPP Contribution Series, Utrecht.

Remy, R. 1959. Die Sporen von Cingularia typica Weiss. Monatsberichte der Deutschen Akademie der Wissenschaften zu Berlin 1(4), 257-261.

Serret, L. \& Brousmiche, C. 1987. Quelques fructifications de Calamitaceae (Arthrophytes) recoltées dans le bassin houiller Sarre-Lorraine (organisation-spores in situ). Palaeontographica B 203(4/6), 135-179.

SCHIMPER, W.P. 1869. Traité de Paléontologie végétales. 738 pp. Baillière, Paris.

Simpson-Scharold, E. 1934. Zur Kenntnis der Carbonflora des Saargebietes. Palaeontographica B 79, 1-66.

Smith, A.H.V. \& Butterworth, M.A. 1967. Miospores in the coal seams of the Carboniferous of Great Britain. Special Papers in Palaeontology 1, 1-324.

STERNBERG, K. 1820-1838. Versuch einer geognostisch-botanischen Darstellung der Flora der Vorwelt. Hefte 1, 24 pp. Hefte 2, 33 pp. Hefte 3, 39 pp. Hefte 4, XLII + 48 pp. Hefte 5 und 6, IV + 80 pp. Hefte 7 und 8, 145 pp. Regensburg, Leipzig, Prague. 